\title{
Drought Resistance in Wheat (Triticum aestivum L.): A Review
}

\author{
Raveena $^{1^{*}}$, Richa Bharti ${ }^{1^{*}}$ and NeelamChaudhary ${ }^{2}$ \\ ${ }^{1}$ Chandigarh University, Gharuan, Mohali, India \\ ${ }^{2}$ PDM, university, Bahadurgarh (Delhi NCR), India \\ *Corresponding author
}

\section{A B S T R A C T}

\section{Keywords}

Drought, stress, proline, tolerance, transpiration.Areca nut, UHPLC, Redox titration, Vitamin $\mathrm{B}_{6}$, Vitamin C

\section{Article Info}

\section{Accepted:}

20 August 2019

Available Online:

10 September 2019

\begin{abstract}
Wheat is an important cereal crop grown worldwide primarily for chapati, bread and biscuits. Target specific wheat breeding and quality improvement programs focus on developing genetically superior, high yielding, disease resistant cultivars with desired quality that are adapted to different growth environments. Drought refers to the condition of reduced soil moisture which induces several changes in crops i.e., morphological, biological, physiological and molecular changes. It also causes reduction in crop yield or in some cases cause crop failure. Rain-fed areas are more likely to face such conditions. These condition leads to the financial crisis among farmers whose major occupation is agriculture. Drought effects the crops in terms of its morphology, productivity etc. The essential stages of crop growth i.e., vegetative and reproductive are more likely to get affected. Some plants however possess mechanisms to tolerate such conditions. Drought decreases the crop production to $50 \%$. Tolerance against water stress is a difficult parameter in which the performance of a crop is influenced by several characteristics i.e., biotic factors such as temperature fluctuations, high irradiance, and nutrient deficiencies and toxicities, can challenge crop plants. hence the breeding of drought tolerance is a very difficult task as it is influenced by various polygene's and their expression and due some environmental factors. Therefore various Approaches like quantitative trait locus (QTL) mapping, marker assisted breeding, and introgression from wild gene pool are being employed to improve drought tolerance. This review herby provides information about the new emerging technologies for the production of drought resistant genotype.
\end{abstract}

\section{Introduction}

Wheat (Triticum aestivum L.) is a member of the family Poaceae, the largest family within the monocotyledonous plants. Wheat is the world's most favoured staple food crop and contributes nearly about two billion people (36\% of the world population), provides nearly $55 \%$ of the carbohydrates and $20 \%$ of the food calories consumed globally (Breiman and Graur, 1995).It is the world's largest cereal crop species because of the acreage it occupies, high productivity and the prominent position it holds in the international food grain trade. The common bread wheat, Triticum aestivum is the most important species, occupying more than $90 \%$ of the total wheat area in the country. Bread wheat is a self- 
pollinating, a hexaploid annual plant (AABBDD) with total number of 42 chromosomes. Wheat is the world's most favoured staple food crop and contributes nearly of the total food grains production. The crop is sensitive to drought and heat stresses, particularly during flowering and grain filling stages, notably by increased recurrent droughts associated with global climate change (Edossa et al., 2014).

\section{Drought}

The definition of drought reflects many disciplinary perspectives including the meteorologist who views it as the lowest amount of annual precipitation and the agronomist who assesses yield loss attributable to water deficit.

\section{Types of drought}

Drought is classified into three major categories (Dai, 2011): (i) agricultural drought; (ii) meteorological drought; and (iii) hydrological drought.

Drought is the most important limiting factor for crop production and it is becoming an increasingly severe problem in many regions of the world. In addition to the complexity of drought itself (Passioura, 1996 and Passioura, 2007).Tolerance of a crop plant against water stress is categorized as drought avoidance and dehydration tolerance. Drought avoidance generally involves deep root zone depth, early planting of crops, by planting drought resistant varieties. Breeding for drought tolerance requires dedicated research efforts and collaborations among growers: Local, regional and global governmental and NGO scientists. This allows sharing of genetic resources, research facilities and advanced technologies (Mwadzingeni et al., 2016a).Over a wide range of stress and non-stress environments, the ability of a cultivar to produce high and satisfactory yield is very important (Rashid et al., 2003). The response of plants to water stress depends on several factors such as developmental stage, severity and duration of stress and cultivar genetics (Beltrano and Marta, 2008). It is very important to identify appropriate traits that are known as drought tolerant traits in any drought experiment. some morphological characters such as root length, tillering, spike number per $\mathrm{m}^{2}$, grain number per spike, number of fertile tillers per plant, 1000 grain weight, peduncle length, spike weight, stem weight, awn length, grain weight per spike and affect wheat tolerance to the moisture shortage in the soil (Jhonson et al.,1983; Moustafa et al., 1996; Plautet al., 2004; Blum, 2005).There are various factors that can affect the plant responses to drought such as growth rate, severity, plant genotype, and duration of stress, activity of photosynthetic machinery, respiration transpiration and environmental factors. Plants with drought tolerance in them tries to have less water reduction and less photosynthetic activity the tolerant plant tries to acquire more of soluble sugars, proline content, amino acids, chlorophyll content and enzymatic and non-enzymatic antioxidant activities. The physio-morphological traits of a plant are very essential for selection in a breeding program, this will help to improve drought tolerance in a plant due to their relation to the adaption for future climate scenarios. Hence identification of the genes and controlling the physiological changes may lead to the fruitful outcome as a drought tolerant species. Genetic improvement in wheat needs to be continued as it is crucially important because of its direct impact on economic development, international grain trade and food security. there are certain researches going on which different breeding lines are compared which have some weird and wonderful traits for drought tolerance for example reduced tillering, reduced awns or no awns at all, higher waxiness on the leaves or better 
carbohydrates storage in the stem which allows it to feel better once it's flowered. These traits are placed in using plant breeding into various different genetic backgrounds so that they can be compared in something that's relevant to withstand such conditions.

\section{Physiological parameters of Drought Tolerance in Wheat}

Physiological characters are the yield stability parameters and could be useful for evaluating drought tolerance wheat genotypes while a biochemical character plays a role in osmotic adjustment including stabilization of cell membrane under stress conditions. Physiological responses include closure of stomata, decrease in the activity of photosynthesis, development of oxidative stress, alteration in the integrity of cell wall, production of metabolites which are toxic and cause plants death (Bray, 2002). According to researchers, there is a relationship between different physiological responses of crops and their resistance functions under drought such as high amount of relative water and potential water (Clark and McCaig, 1982; Ritchie et al., 1990)and integrity of membrane (Sairam et al.,1990).Leaf relative water content indicates the water status of plants relative to their fully turgid state (Moayedi et al., 2011). Genotypes that maintain high levels of leaf water under water deficit conditions are less affected by stress and are able to maintain normal growth and yield (Beltrano et al., 2006). In wheat, water balance among genotypes is disrupted when relative water content decreases in leaves under water deficit conditions (Molnar et al., 2004; Dulai et al., 2006) and a positive correlation between grain yield and leaf relative water content has been observed (Schonfeld et al., 1988; Tahara et al., 1990; Merah 2001).If water retention capacity of wheat genotypes is increased, the yield of rainfed wheat could be increased or at least stabilized. The selection of leaf relative water content traits for breeding under drought stress conditions has therefore been emphasised(Schonfeld et al., 1988).For measuring drought tolerance, various scientists considered maintenance of membrane integrity and its role under water stress (Premachandra et al., 1990; Deshmukh et al., 1991). Growth is one of the physiological processes which is sensitive to drought and can be affected by reduction in turgor pressure. Because of low turgor pressure, water stress quenches cellexpansion and growth. However, when turgor pressure isbigger than the cell wall yield, cell expansion can occur (Karthikeyan et al., 2007; Jaleel et al., 2007). Osmotic adjustment is a remarkable part of plants' physiology by which they respond to water deficits (Erdei et al., 2002; Munns, 2002; Maathuis et al., 2003).The objective in many breeding programs is to develop cultivars tolerant to drought stress but success has been limited. Genetic improvement of stress tolerance in crop plants requires identification of relevant physiological stress tolerance mechanisms as selection criteria (Morgan, 1977) and testing to verify the value of such criteria for improvement of stress tolerance. Osmotic adjustment (OA) is generally considered an important component of drought resistance (Ludlow and Muchow, 1990). Osmotic adjustment (OA) strongly depends on the rate of plant water stress. OA requires time, and fast reduction in plant water status does not allow time for adjustment. This is very significant when genotypes are compared for their OA capacity. However, the importance of the time and the rate of stress for the development of OA imply that OA may not be a very effective mechanism of drought resistance under conditions where the development of drought is by nature very rapid, such on very light tropical or sandy soils of very low water holding capacity (Blum, 1996). It was recently shown that a population issued from an inland desert 
area displayed a higher ability for $\mathrm{OA}$ in drought conditions than a population originating from a salt-affected coastal site (Mart"Inez, et al., 2003). These contrasting populations provide interesting material with which to (i) quantify the relative contribution of various osmolytes to $\mathrm{OA}$ and (ii) to determine the importance of $\mathrm{OA}$ in the adaptative response of Atriplexhalimus to water stress. Leaf relative water content (RWC) was a better indicator of water status than was water potential (M Sinclair and Ludlow, 1985).Martinet al., (2009) stated that RWC of bean leaves under drought stress significantly was lesser than control. Lazacano-Ferrat and Lovat, (1999)subjected bean plant to drought stress and after 10, 14 and 18 days after irrigation was with holded, they evaluated RWC of stem and found RWC was significantly lower comparing with control plants. Gaballah et al., 2007applied antitranspirant maters on two Sesame cultivars named Gize 32 and Shanavil 3 and observed that this matters by preventing water transpiration from leaves, led to increase in RWC in these cultivars. Specific leaf area (SLA), an indicator of leaf thickness, has often been observed to be reduced under drought conditions (Marcelis et al., 1998).The opening and closure of stomata, decreased photosynthetic activity, production of metabolites, integrity of cell wall, production of metabolites, reduced $\mathrm{CO}_{2}$ concentration signal, turgor loss are the physiological parameters that defines the performance of the wheat in such drastic conditions. Gloucousness is another feature that conserves water content under water deficit by reducing transpiration (Farooqet al., 2009).Transpiration contributes to $90 \%$ of water loss through its stomatal openings. Maintaining better stomatal control over transpiration is critical for combating photosynthesis inhibition under drought stress (Bota et al., 2004). Significant genetic variation for stomatal size and density has been reported in wheat (Baloch et al.,2013) carbon assimilation and internal plant water status totally rely on stomatal openings and closing. Stomatal pores helps to control both transpiration rate and uptake of $\mathrm{CO}_{2}$ thus have a major role in photosynthetic activity. Maintenance of membrane integrity plays important role to withstand dry spells. Well photosynthesis is known as the main driver of plant growth and grain yield. The role of photosynthesis in physiological responses in plant response is difficult to understand. Disparity in photosynthetic pigments tells us about the magnitude of photosynthesis in plant under water stress conditions. Drought decreases the photosynthesis rate of a plant.

Researchers had found that there is a relationship between the physiological responses of crops and resistance functions such as potential water and high amount of relative water. Maintenance vital component that assist the photosynthesis rate is $\mathrm{CO} 2$. Metabolic distortions of photosynthetic activity could be due to an uneven utilization of light that is consumed by the plant, decreased activity of Rubisco, loss of chloroplast membrane, degeneration of photosynthesis apparatus and chloroplast structure. Closure of stomata during water stress conditions limits the loss of water. Plant hormones plays important role in plants to accustomed the plants to varying drought conditions. Abscise acid (ABA) is considered to the main hormones to helps the plants to tolerate such conditions through mechanisms like deep root penetration, stomata regulation (opening and closing) and initiation of ABAdependent pathway. Other phytohormones like jasmonic acid (JA), salicylic acid (SA) ethylene (ET), auxins (IAA), gibberellins (GAs), cytokinins (CKs), and brassinosteroids (BRs) to help the plants to withstand water stress conditions. Transgenic approaches are mostly preferred for the production of genes which helps in the synthesis of 
phytohormones.

\section{Biological Parameters}

Rauf, et al., 2007 stated that water stress conditions leads to reduced photosynthetic potential by decreasing photosynthesis rate per unit area and leaf area both while Landjeva, et al., 2008 suggested that Photosynthetic rate is chiefly reduced through stomatal movement or metabolic impairment. Depending upon the stress intensity, seedling stage drought may be more detrimental to yield in comparison to stress at later growth stages (Maccaferri, et al.,2011).A reduction in efficiency of photochemical, reduced Rubisco efficiency, gathering of stress metabolites (glutathione and polyamines), antioxidative enzymes (superoxide dismutase (SOD), peroxidase (POD), catalase (CAT), ascorbate peroxidase (APX)) and reduced ROS accumulation are biochemical responses of plants to water stress. Changes in activity of these enzymes are crucial for the resistance of various plants to drought stress (Rensburg and Kruger, 1994). Evidences suggest that drought causes oxidation damage from increased production of ROS with deficit defense system of antioxidant in plants (Seki et al., 2002; Chen and Gallie, 2004; Chinnusamy et al., 2004). In wheat, various studies exhibited that wheat genotypes with higher osmotic regulators and lower malondialdehyde (MDA) content have better tolerance to drought (Tang, 1983; Chandler and Bartels, 2003; Chen and Gallie, 2004; Apel and Hirt, 2004; Dhanda et al., 2004). Polyamines (PAs) have a role in the completeness of membranes and nucleic acid under water stress environments (Szegletes et al., 2000). Malabika and $\mathrm{Wu}$ (2001) mentioned that higher levels of polyamines can make crops have higher growth under water stress conditions (An and Wang, 1997; Bouchereau et al., 1999). CAT is one of the most rapidly reversible proteins in leaf cells especially in stress conditions and its activity is reduced in drought condition (Hertwig et al., 1992).Proline is among key biochemicals that accumulate in significant proportions in plants that are exposed to various kinds of stress, including dehydration (Hong-Boa et al., 2006; Khamssi, 2014).Proline, which is an $\alpha-$ amino acid, has been associated with several osmoprotection roles, including; osmotic adjustment (Marek et al., 2009; Zadehbagheri et al., 2014), membrane stabilization (Hayat et al., 2012), and gene signaling to activate antioxidizing enzymes that scavenge reactive oxygen species (ROS) (de Carvalho et al., 2013). Saeedipour (2013) reported that proline content accumlated faster and in higher proportions in drought tolerant genotypes than sensitive counterparts under drought-stress conditions suggesting its value in breeding for drought tolerance. Proline content has been reported to be controlled by genes with additive effects by Maleki et al., (2010).Limited water supply decreases chlorophyll formation (Begum and Paul, 1993), chlorophyll content (Beltrano and Ronco, 2008; Nikolaeva et al., 2010), plant growth and yield by accelerating leaf senescence (Sionit et al., 1980; Ashraf et al., 1994). Variation in chlorophyll concentration among genotypes is controlled mainly by genes acting additively (Hervé et al., 2001; Juenger et al., 2005).

\section{Morphological Parameters}

Special attention to the morphological traits is paid during moisture stress like leaf (shape, expansion, area, size, senescence, pubescence, waxiness, and cuticle tolerance) and root (dry weight, density, and length).It has been found that drought can affect both vegetative and reproductive stages of the plant crop.

During the screening for drought tolerance at seedling stage, reports are available on the correlation between drought tolerance at seedling stage and reproductive stage in wheat. The traits have used for screening of 
germplasm for drought tolerance are seedling survival, dry weight, root shoot ratio and root length, relative water content and seed reserve mobilization. Wheat has paid special attention due to its morphological traits during drought stress including leaf (shape, expansion, area, size, senescence, pubescence, waxiness, and cuticle tolerance) and root (dry weight, density, and length). Rizzaet al., (2004) observed that early maturity, small plant size, and reduced leaf area can be related to drought tolerance. Lonbani and Arzani (2011) claimed that the length and area of flag leaf in wheat increased while the width of the flag leaf did not significantly change under drought stress. According to the study of Rucker et al., (1995), drought can reduce leaf area which can consequently lessen photosynthesis. Root is an important organ as it has the capability to move in order to find water (Hawes et al., 2000). It is the first organ to be induced by drought stress (Shimazaki et al., 2005). In drought stress condition, roots continue to grow to find water, but the airy organs are limited to develop. This different growth response of shoots and roots to drought is an adaptation to arid conditions (Sharp and Davis, 1989; Spollen et al., 1993). To facilitate water absorption, root-to-shoot ratio rises under drought conditions (Morgan, 1984; Nicholas, 1998) which are linked to the ABA content of roots and shoots (Rane and Maheshwari, 2001). The growth rate of wheat roots was diminished under moderate and high drought conditions (Noctor and Foyer, 1998). Plant biomass is a crucial parameter which was decreased under drought stress in spring wheat (Wang et al., 2005). The epicuticular waxes covering the aerial parts of plants play an important role in the control of water flow across the cuticle (Eigenbrode and Espelie, 1995). They help leaves retain water (Jordan et al.,1984) by minimizing cuticular transpiration (Premachandra et al.,1992b; Jefferson, 1994). Theyalso shield plants from high radiation and UV light damage by providing the leaves with greater reflectance (Grant et al., 1995). Its role in reducing cuticular transpiration and improving drought resistance is evident in sorghum and wheat (Blum, 1988b) and genotypes with low cuticular transpiration rates usually have a functional advantage during water deficit due to more efficient water use (Paje et al., 1988). Therefore it is very necessary to understand the response of the plant at various stages during water stress conditions the basic concept is thereby than help us to engineer crops with water stress resistance and make us more progressive in terms of breeding. Scientists have observed that characters early maturity, relatively small plant size, and reduced leaf area can be related to drought tolerance. Scientist has claimed that the significant area of the flag leaf in wheat is increased while there is no significant effect of water stress on the width of flag leaf in wheat. During the water stress condition the leaf extensions also become limited in order to maintain the balance between the water absorbed by the roots and the water status of the plant tissues. According to the study of Rucker, drought can reduce leaf area which can consequently lessen photosynthesis. The leaf size number of leaves per plant, and longevity of the leaf is shrunk due to water stress.It has been found that during leaf development in wheat is more susceptible to water stress condition. In water stress conditions roots of a plant continue to grow, but the development of the airy organs becomes restricted.

Under moderate or high drought conditions the growth rate of roots starts getting diminished. The yield of wheat crop under drought conditions starts decreasing until the water use efficiency is enhanced.

\section{Molecular Responses}

Recent developments in molecular genetics 
have strengthened the breeders with powerful tools to identify and select complex traits. Association between markers and traits reduce the influence of environment which is a major hindrance in conventional selection of complex quantitative traits (Tuberosa and Salvi, 2006). Wheat exhibits low level of polymorphism compared to other cereals, and polymorphism also varies amongst the genomes, with the D-genome being the least polymorphic (Akhunov et al., 2010). The low polymorphism has in turn slowed genetic mapping studies in wheat compared to other cereals as the level of polymorphism affects marker density (Fleury et al., 2012). The complexity of the wheat genome further complicates genetic mapping, analysis, genome sequencing and gene discovery (Edwards et al., 2012). Both dominant and codominant markers have been extensively used in genetic mapping in bread wheat (Chalmers et al., 2001; Crossa et al., 2007; Sherman et al., 2010; Uphaus et al., 2007). Numerous molecular markers designed based on known sequence polymorphisms in specific genes for which the functions have been studied are routinely used in genotyping of wheat mapping populations (Liu et al., 2012). Many investigators concluded that SSR molecular markers are significantly associated with wheat traits related to salinity tolerance (Munir et al., 2013) and drought tolerance (Ivandiç et al., 2002, Liviero et al., 2002, Quarrie et al.,2003, Ciuca and Petcu 2009, Abd El-Hadi, 2012 and Suhas et al.,2012).Marker aided selection significantly increases the efficiency of selection by including approaches like marker assisted backcross breeding (MABB), and marker assisted recurrent selection (MARS). Some genes are known to produce drought stress proteins and enzymes dehydrins, vacuolar acid invertase, glutathione S-transferase and late embryo abundant (LEA) protein ; expression of ABA genes and production of some proteins like RAB, proline, rubisco, helicase, and carbohydrates, these are known to be the molecular basis of drought. During drought conditions plants respond to water stressed environment by altering their gene expressions and protein production. Sivamani et al., indicated that HVA1 gene assists to increase wheat growth under drought stress. HVA1 gene is known for the production of protein which is in group 3 LEA and has 11 amino acid motifs in nine repeats. Proline is also known as antidrought protein in wheat under drought. Proline can be created from pyrroline-5-carboxylate synthetase or P5CR, and the gene which is responsible for this enzyme has been found in some crops, like petunia, soybean, and tobacco.

\section{Breeding Approches}

Breeding can be done through various methods which are classified as conventional and biotechonological approaches. Conventional breeding methods involves the detections of genetic variability among different genotypes, or sexually compatible cultivars, followed by the introduction of tolerance traits. In conventional breeding method. Conventional breeding is referred as a long process which totally relies on the availability of required genes. This process requires proper attention as it is very difficult to identify and separate desirable and undesirable traits. For example, some crops are backcrossed again and again to identify non desirable characters/traits. Conventional methods are therefore not economically fruitful.

Whereas in comparison to conventional methods, biotechnological approaches are not laborious as does conventional and take less time for the development of new variety with desirable traits. Biotechnological approaches took breeding to a whole new level. In genetic engineering the sequence or the genes are altered in such a tremendous manner to have a 
suitable output.

Researches in plant breeding are essential to produce new varieties of wheat with high degree of water stress tolerance in wheat. In case of genetic engineering improvements are done by identifying the genetic dominants and transferring them to the plants so that they can act against water stress. It is very difficult to manage the drought tolerance in traditional breeding. Drought effects vast number of genes and their functions. Elite genotypes are selected to not only overcome the water stress problem but as well as high yield. Identification of the genes controlling physiological changes that helps the plant to tolerate the water stress conditions is necessary to have rapid genetic improvement in a plant. Lots of drought resistant genes were detected and cloned. The very initial step for genetic improvement is to select the germplasm holding the potential to withstand water stress conditions. After the selection of the potential genotypes, breeding program me begins by crossing the potential genotypes as donor parent. The genetic alternation for water stress tolerance are attained by recognizing the potential genotypes controlling drought using GWAS or QTL mapping. Moreover, other editing's and alternations in the genomic sequences are carried out to improve the drought tolerance in wheat. Fusion of information from three vital area i.e., genetics, physiology and breeding assist to find out more number of genotypes that carry the potential to withstand water stress conditions. Genetic engineering and molecular markers made the production and generation of improved drought resistant genes very easy and reliable.

Transgenic crops are modified in such a way that they will undergo and perform their level best even under water stress conditions. Agrobacterium and gene gun techniques are used for transferring transgenes related to water stress conditions into the crop.

\section{References}

Abd El-Hadi, A. A. 2012. Molecular characterization of some durum wheat drought tolerant mutants by RAPD and ISSR analysis.Arab J. Biotech., 15(1): 77-90.

Akhunov, E. D., Akhunova, A. R., Anderson, O. D., Anderson, J. A., Blake, N., Clegg, M. T., Coleman-Derr, D., Conley, E. J., Crossman, C. C., Deal, K. R., Dubcovsky, J., Gill, B. S., Gu, Y. Q., Hadam, J., Heo, H., Huo, N., Lazo, G. R., Luo, M. C., Ma, Y. Q., Matthews, D. E., McGuire, P. E., Morrell, P. L., Qualset, C. O., Renfro, J., Tabanao, D., Talbert, L. E., Tian, C., Toleno, D. M., Warburton. M. L., You, F. M., Zhang, W. and Dvorak, J. 2010. Nucleotide diversity maps reveal variation in diversity among wheat genomes and chromosomes. BMC Genomics 11:702.

An, L.-Z.and Wang, X.-L. 1997. Changes in polyamine contents and arginine decarboxylase activity in wheat leaves exposed to ozone and hydrogen fluoride. Journal of Plant Physiology, 150(12): 184-187.

Apel, K. and Hirt, H. 2004. Reactive oxygen species: metabolism, oxidative stress, and signal transduction. Annual Review of Plant Biology, 55: 373- 379.

Ashraf, M. Y., Azmi, A. R., Khan, A. H., and Ala, S. A. 1994. Effect of water stress on total phenols, peroxidase activity and chlorophyll content in wheat (Triticum aestivum L.).Acta PhysiologiaePlantarum, $16(3)$ : 185-191.

Baloch, M. J., Baloch, E., Jatoi, W. A., Veesar, N. F., Shah, J. A., Depar, N. and El-Deeb, H. M. 2013. Correlations and heritability estimates of yield and yield attributing traits in wheat (Triticum aestivum L.). Pakistan Journal of Agriculture, Agricultural Engineering, Veterinary Sciences, 29(2): 96-105.

Beltrano, J. and Marta, G. R. 2008. Improved tolerance of wheat plants (Triticum aestivum L.) to drought stress and rewatering by the arbuscularmycorrhizal fungus Glomusclaroideum: Effect on growth and cell membrane stability. Braz. J. Plant Physiol.,20(1): 29-37.

Beltrano, J. and Ronco, M.G. 2008. Improved 
tolerance of wheat plants (Triticum aestivum L.) to drought stress and rewatering by the arbuscularmycorrhizal fungus Glomusclaroideum: effect on growth and cell membrane stability. Brazilian Journal of Plant Physiology, 20: 29-37.

Benbelkacem, A. (1996). Etude de 1' adaptatation variegate des cereals cultivees en Algerie sous differentes conditions agroecologiques. Cerealic.31: 17-22.

Blum, A. 1988. Plant Breeding for stress environments.CRC Press, Inc. Boca Raton.

Blum, A. 1996.Crop responses to drought and the interpretation of adaptation.Plant Growth Regulations, 20: 135-148.

Blum, A. 2005. Drought resistance, water use efficiency and yield potential- are they compatible, dissonant, or mutually exclusive? Australian $J$ Agricultural Research, 56: 1159-1168.

Bota, J., Flexas, J. and Medrano, H. 2004. Is photosynthesis limited by decreased Rubisco activity and RuBP content under progressive water stress? New Phytol.162: 671-681.

Botai, C. M.,Botai, J. O., de Wit, J. P.,Ncongwane, K. P. and Adeola, A. M. 2017. Drought Characteristics over the Western Cape Province, South Africa.Water, 9: 876.

Bouchereau, A., Aziz, A., Larher, F. and MartinTanguy, J. 1999. Polyamines and environmental challenges: recent development. PlantScience, 140: 103-125.

Bray, E. A. 2002. Abscisic acid regulation of gene expression during water-deficit stress in the era of the Arabidopsis genome.Plant Cell Environment, 25:153-161.

Breiman, A. and Graur, D. 1995. Wheat evaluation.Israel Journal Plant Sciences,43: 58-95.

Chalmers, K. J., Campbell, A. W., Kretschmer, J., Karakousis, A., Henschke, P. H., Pierens, S., Harker, N., Pallotta, M., Cornish, G. B., Shariflou, M. R., Rampling, L. R., McLauchlan, A., Daggard, G., Sharp, P. J., Holton, T. A., Sutherland, M. W., Appels, R. and Langridge, P. 2001. Construction of three linkage maps in bread wheat, Triticum aestivum .Australian Journal of Agricultural Research, 52: 1089-1119.

Chandler, J. W. and Bartels, D. 2003.Drought avoidance and drought adaptation.Encyclopedia of Water Science, pp.163-165.
Chen, Z. and Gallie, D. R. 2004. The ascorbic acid redox state controls guard cell signaling and stomatal movement. Plant Cell, 16: 11431162.

Chinnusamy, V., Jagendorf, A. and Zhu, J. K. 2005.Understanding and Improving Salt Tolerance in Plants.Crop Science, 45: 437448.

Ciucă, M. and Petcu, E. 2009.Romanian Agricultural Research,26: 21-24.

Clarke, J. and McCaig, T. 1982. Evaluation of techniques for screening for drought resistance in wheat.Journal of Crop Science, 22: 503-506.

Crossa, J., Burgueno, J., Dreisigacker, S., Vargas, M., HerreraFoessel, S. A., Lillemo, M, Singh, R. P., Trethowan, R., Warburton, M., Franco, J., Reynolds, M., Crouch, J. H. and Ortiz, R. 2007. Association analysis of historical bread wheat germplasm using additive genetic covariance of relatives and population structure.Genetics, 177:18891913.

de Carvalho, K., de Campos, M. K. F., Domingues, D. S., Pereira, L. F. P., and Vieira, L. G. E. 2013. The accumulation of endogenous proline induces changes in gene expression of several antioxidant enzymes in leaves of transgenic Swinglecitrumelo, Molecular Biology Report. 40: 3269-3279.

Deshmukh, P. S., Sairam, R. K. and Shukla, D. S. 1991. Measurement of ion leakage as a screening technique for drought resistance in wheat genotypes.Indian J. Plant Physiology,34: 89-91.

Dhanda, S. S., Sethi, G. S. and Behl, R. K. 2004. Indices of drought tolerance in wheat genotypes at early stages of plant growth.Journal of Agronomy and Crop Science, 190: 6-12.

Dulai, S., Molnár, I., Prónay, J., Csernak, A., Tarnai, R., MolnárLáng, M. 2006.Effects of drought on photosynthetic parameters and heat stability of PSII in wheat and in Aegilops species originating from dry habitats.ActaBiologicaSzegediensis,50: 1117.

Edwards, D. and Wang, X. 2012.Genome sequencing initiatives. In: Edwards D, Parkin IAP, Batley J (eds) Genetics, genomics and breeding of oilseed brassicas. Science Publishers Inc., New Hampshire, (USA),pp 152-157. 
Eigenbrode, S. D. and Espelie, K. E. 1995.Effects of Plant Epicuticular Lipids on Insect Herbivores.Annual Review of Entomology, 40: 171-194.

Erdei, L. Tari, I. and Csisz ' aretal, J. I. 2002. Osmotic stress responses of wheat species and cultivars differing in drought tolerance : some interesting genes (advices for gene hunting). ActaBiologicaSzegediensis, 46: $63-65$.

Farooq, J., Khaliq, I. and Mahmood, A. 2014.Evaluation of Some Wheat Hybrids under Normal and Heat Stress Conditions. Triticale Genomics and Genetics, 5(2):1-11.

Fleury, D., Baumann, U. and Langridge, P. 2012. 6 Plant genome sequencing: Models for developing synteny maps and association mapping, in: A. Arie and H. Paul Michael (Eds.), Plant Biotechnology and Agriculture, Academic Press, San Diego. pp. 83-97.

Gaballah, M. S., AbouLeila, B., El-Zeiny, H. A. and Khalil, S. 2007. Estimating the Performance of Salt-stressed Sesame Plant Treated with Antitranspirants.J. Appl. Sci. Res.,3(9): 811817.

Grant, R. H., Jenks, M. A., Rich, P.J., Peters, P. J. and Ashworth, E. N. 1995.Scattering of ultraviolet and photosynthetically active radiation by sorghum bicolor: influence of epicuticular wax.Agricultural and Forest Meteorology, 75: 263-281.

Hawes, M. C., Gunawardena, U., Miyasaka, S. and Zhao, X. 2000. The role of root border cells in plant defense. Trends in Plant Science, 5(3): 128-133.

Hayat, S., Hayat, Q., Alyemeni, M. N., Wani, A. S., Pichtel, J., and Ahmad, A. 2012. Role of proline under changing environments: a review. Plant Signal.Behav. 7: 1456-1466.

Hertwig, B., Streb, P. andFeierabend, J. 1992. Light dependence of catalase synthesis and degradation in leaves and the influence of interfering stress conditions. Plant Physiology, 100:1547-1553.

Herve, D., Fabre, F., Berrios, E. F., Leroux, N., Al Chaarani, G., Planchon, C., Sarrafi, A. and Gentzbittel, L. 2001.QTL analysis of photosynthesis and water status traits in sunflower (Helianthus annuus L.) under greenhouse conditions.Journal of experimental botany, 52: 1857-1864.

Hong-Boa, Sh., Xiao-Yan, Ch., Li-Ye, Ch., Xi-Ning, Zh.,Gangh, W., Yong-Bing, Y., Chang-
Xing, Zh. and Zan-Min, H. 2006. Investigation on the relationship of proline with wheat anti-drought under soil water deficits.Colloids and Surfaces B: Biointerfaces, 53: 113-119.

Ivandiç, V., Hackett, C. A., Nevo, E., Keith, R., Thomas, W. T. B. and Forster, B. P. 2002. Analysis of simple sequence repeats (SSRs) in wild barley from the Fertile Crescent: associations with ecology, geography and flowering time. Plant Mol. Biol.,48: 511527.

Jaleel, C. A., Manivannan, P., Wahid, A., Farooq, R., Somasundaram, R. and Panneerselvam, R. 2009 Drought stress in plants: a review on morphological characteristics and pigments composition. International Journal of Agriculture Biology, 11: 100-105.

Jefferson, P. G. 1994. Genetic-variation for epicuticular wax production in altai wild rye populations that differ in glaucousness.Crop science, 34: 367-371.

Johnson, H. W., Robinson, H. F. and Comstock, R. E. 1955.Estimates of genetic and envirionmental variability in soyabean.Agron. J., 47: 314-318.

Jordan, W. R., Shouse, P. J., Blum, A., Miller, F. R. and Monk, R. L. 1984.Environmental physiology of sorghum. II. Epicuticular wax load and cuticular transpiration. Crop Science, 24: 1168-1173.

Juenger, T. E., Mckay, J. K., Hausmann, N., Keurentjes, J. J., Sen, S., Stowe, K. A., and Richards, J. H. 2005. Identification and characterization of QTL underlying whole-plant physiology in Arabidopsis thaliana: $\delta 13 \mathrm{C}$, stomatal conductance and transpiration efficiency. Plant, Cell \& Environment, 28(6), 697-708.

Karthikeyan, B., Jaleel.,Gopi, C. A. R. and Deiveekasundaram, M. 2007 Alterations in seedling vigour and antioxidant enzyme activities in Catharanthusroseusunder seed priming with native diazotrophs. Journal of Zhejiang University Science B, 8:453-457.

Khamssi, N. N. 2014. Leaf proline content and yield performance of wheat genotypes under irrigated and rain-fed conditions. Indian Journal of Fundamental Applied Life Sciences, 14: 95-299.

Landjeva, S., Korzun, V. and Börner, A. 2007. Molecular markers: actual and potential contributions to wheat genome 
characterization

and

breeding.Euphytica, 156: 271-296.

Lazacano-Ferrat, I. and Lovat, C.J. 1999. Relationship between relative water content, nitrogen pools, and growth of Phaseolus vulgaris L. and P. acutifolius A. Gray during water deficit. Crop. Sci., 39: 467-475.

Liu, W. X., Jin, Y., Rouse, M., Friebe, B., Gill, B. and Pumphrey, M. O. 2011. Development and characterization of wheatAe.searsiiRobertsonian translocations and a recombinant chromosome conferring resistance to stem rust. Theoretical and Applied Genetics, 122:1537-1545.

Liviero, L., Maestri, M., Gulli, E., Nevo, N. and Marmiroli. 2002. Ecogeographic adaptation and genetic variation in wild barley, application of molecular markers targeted to environmentally regulated genes, Genet. Resources and Crop Evol., 49: 133-144.

Lonbani, M. and Arzani, A. 2011.Morphophysiological traits associated with terminal drought-stress tolerance in triticale and wheat. Agronomy Research, 9(1/2): 315329.

Ludlow, M. M. andMuchow, R. C. 1990. A critical evaluation of traits for improving crop yields in water limited environments. Advances in Agronomy, 43: 107-153.

M Sinclair, T.R. and Ludlow, M.M. 1985.who taught plants thermodynamics? The unfulfilled potential of plant water potential.Aust. J. Plant Physiol.33: 213-217.

Maathuis, F. J. M., Filatov, V. and Herzyk P. 2003. Transcriptome analysis of root transporters reveals participation of multiple gene families in the response to cation stress. Plant Journal, 35: 675-692.

Maccaferri, M., Sanguineti, M. C., Corneti, S., Ortega, J. L, Salem, M. B, Bort, J., DeAmbrogio, E., del Moral, L. F., Demontis, A., El-Ahmed, A., Maalouf, F., Machlab, H., Martos, V., Moragues, M., Motawaj, J., Nachit, M., Nserallah, N., Ouabbou, H., Royo, C., Slama, A. and Tuberosa, R. 2008. Quantitative trait loci for grain yield and adaptation of durum wheat (Triticum durumDesf) across a wide range of water availability.Genetics, 178:489-511.

Malabika, R. and $\mathrm{Wu}, \mathrm{R}$. Arginine decarboxylase transgene expression and analysis of environmental stress tolerance in transgenic
rice.Plant Science, 160:869-875.

Maleki, A., Jalal, S. and Shekari, F. 2010.Inheritance of proline content in bread wheat (Triticum aestivum L.) under rainfed conditions.Journal of Food Agriculture and Environmental, 8:155-157.

Marcelis, L.F.M., Heuvelink, E. and Goudriaan, J.1998. Modelling biomass production and yield of horticultural crops: a review.Sci. Hort.74: 83-111.

Marek, Ž., Jana, R., Katarína, O., and Brestiè, M. 2009. Osmotic adjustment in winter wheat varieties and its importance as a mechanism of drought tolerance.Cereal Research Communication.37: 569-572.

Mart"Inez, J. P., Ledent, J. F., Bajji, M., Kinet, J. M. andLutts, S. 2003. Effect of water stress on growth, $\mathrm{Nap}$ and $\mathrm{Kp}$ accumulation and water use efficiency in relation to osmotic adjustment in two populations of Atriplexhalimus. Plant Growth Regul, 41: 63-73.

Martin, M., Miceli,F., Morgan, J. A., Scalet, M.and Zerbi, G. 2009. Synthesis of Osmotically Active Substances in Winter Wheat Leaves as Related to Drought Resistance of Different Genotypes.J. of Agro.and Crop Science, 171(3): 176-184.

Merah, O. 2001.Potential importance of water status traits for durum wheat improvement under Mediterranean conditions.The Journal of Agricultural Science 137:139-145.

Moayedi, A. A., Nasrulhaq-Boyce, A. and Tavakoli, H. 2011. Application of physiological and biochemical indices for screening and assessment of drought tolerance in durum wheat genotypes.Australian Journal Crop Sciences5(8):1014-1018.

Molnar, I., Gaspar, L., Sarvari, E., Dulai, A., Hoffmann, B., Molnar-Lang, M. and Galiba, G. 2004. Physiological and morphological responses to water stress in Aegilopsbiuncialis and Triticum aestivum genotypes with differing tolerance to drought. Functional Plant Biology, 31: 1149-1159.

Morgan, J.M. (1977 b).Differences in osmoregulation between wheat genotypes.Nature (London)270: 234-235

Morgan, J. M. 1984. Osmoregulation and water stress in higher plants. Annual Review of Plant Physiology, 35: 299-319.

Moustafa, K. A., Saleh, M., Al-Doss, A. A., Elshafei, 
A. A., Salem, A. K., Al- Qurainy, F. H. and Barakat, M. N.2014. Identification of TRAP and SRAP markers linked with yield components under drought stress in wheat (Triticum aestivum L.). Plant Omics Journal, 7(4):253-259.

Munir, A., Armghan, S., Iqbal, M., Asif, M. and Hirani, A. H. 2013.Austr. J. Crop Sci., 7(I), 66-74.

Munns, R. 2002. Comparative physiology of salt and water stress.Plant Cell and Environment, 25: 239-250.

Mwadzingeni, L., Shimelis, H., Dube, E., Laing, M. D., and Tsilo, T. J. 2016. Breeding wheat for drought tolerance: Progress and technologies. J. Integr. Agr.15: 935-943.

Nicholas, K. B. and Nicholas, H. B. 1997. Gene Doc: A tool for editing and annotation multiple sequence alignments. Distributed by the author (www.psc.edu/biomed/genedoc).

Nikolaeva, M. K., Maevskaya, S. N., Shugaev A. G., Bukhov N. G., 2010. Effect of drought on chlorophyll content and antioxidant enzyme activities in leaves of three wheat cultivars varying in productivity.Russian Journal of Plant Physliology, 57: 87-95.

Noctor, G. and Foyer, C. H. 1998.Ascorbate and glutathione: Keeping active oxygen under control. Plant Mol Biol.,49: 249-279.

Paje, M., Ludlow, M. and Lawn, R. 1988.Variation among soybean (Glycine max (L.)Merr.)accessions in epidermal conductance of leaves. Crop and Pasture Science, 39: 363-373.

Passioura, J. B. 1996. Drought and drought tolerance.Plant Growth Regulation, 20: 7983.

Passioura, J. B. 2007. The drought environment: physical, biological and agricultural perspectives. Journal of Experimental Botany, 58:113-117.

Plaut, Z. 2003. Plant exposure to water stress during specific growth stages.Encyclopedia of Water Science, Taylor \& Francis,pp. 673675.

Premachandra, G. S., Saneoka, H. and Ogata, S. 1990. Cell membrane stability an indicator of drought tolerance as affected by applied nitrogen in soyabean. Journal of Agricutural Sciences, 115: 63-66.

Premachandra, G. S., Saneoka, H., Fujita, K. and Ogata, S. 1992. Leaf water relations, osmotic adjustments, cell membrane stability, epicuticular wax load and growth as affected by increasing water deficit in Sorghum.Journal of experimental botany, 43 : 1569-1576.

Quarrie, S. A., Dodig, D., Pekiç, S., Kirby, J. and Kobiljski, B. 2003. Prospects for markerassisted selection of improved drought responses in wheat.Bulg. J. Plant Physiol., Special Issue, 83-95.

Rane, J. M. and Maheshwari, S. N. 2001.Effect of pre-anthesis water stress on growth, photosynthesis and yield of six wheat cultivars differing in drought tolerance.Indian Journal of Plant Physiology, 6: 53-60.

Rashid, M., Cheema, A. A. and Ashraf, M. 2007.Heterosis and combining ability as well as the gene action on yield and yield components.Pakistan Journal of Botany,39(6): 2035-2042.

Rauf, M., Munir, M., Hassan, M., Ahmad, M. and Afzal, M. 2007.Performance of wheat genotypes under osmotic stress at germination and early seedling growth stage.Afr J Biotechnol,6(8): 971-975.

Rensburg, L.V. and Kruger, G. H. J. 1994.Evaluation of components of oxidative stress metabolism for use in selection of drought tolerant cultivars of Nicotianatabacum L. Journal of Plant Physiology, 143: 730-737.

Ritchie, S. W., Nguyen, H. T. andHoladay, A. S. 1990. Leaf water content and gas exchange parameters of two wheat genotypes differing in drought resistance. Crop Science, 30: 105-111.

Rizza, F., Badeck, F. W., Cattivelli, L., Lidestri, O., Fonzo Di, N., and Stanca, A. M. 2004. Use of a water stress index to identify barley genotypes adapted to rainfed and irrigated conditions. Crop Sci.,44: 2127-2137.

Rucker, K. S., Kevin, C. K., Holbrook, C. C. and Hook, J. E. 1995. Identification of peanut genotypes with improved drought avoidance traits. Peanut Sci., 22: 14-18.

Saeedipour, S. 2013. Relationship of grain yield, $\mathrm{ABA}$ and proline accumulation in tolerant and sensitive wheat cultivars as affected by water stress.Proc. Natl.Acad. Sci. U.S.A., 83: 311-315.

Sairam, R. K., Deshmukh, P. S., Shukla, D. S. and Ram, S. 1990. Metabolic activity and grain yield under moisture stress in wheat genotypes. Ind. J. Plant Physiol., 33: 266- 
231.

Schonfeld, M. A., Johnson, R. C., Carver, B. F. and Mornhigweg, D. W. 1988. Water relations in winter wheat as drought resistance indicators.Crop Science, 28: 526-531.

Seki, M., Narusaka, M., Ishida, J., Nanjo, T., Fujita, M., Oono, Y., Kamiya, A., Nakajima, M., Enju, A. and Sakurai, T. 2002. Monitoring the expression profiles of 7000 Arabidopsis genes under drought, cold and high-salinity stresses using a full-length cDNA microarray. Plant Journal,31:279-292.

Sharp, R. E. and Davis, W. J. 1989.Regulation of growth and development of plants growing with a restricted supply of water. In: Jones HG, Flowers TJ, Jones MB, editors. Plant under Stress. Cambridge, UK: Cambridge University Press, pp. 71-93.

Sherman, J. D., Weaver, D. K., Hofland, M. L., Sing, S. E., Buteler, M., Lanning, S. P., Naruoka, Y., Crutcher, F., Blake, N. K., Martin, J. M., Lamb, P. F., Carlson, G. R. and Talbert, L. E. 2010. Identification of Novel QTL for Sawfly Resistance in Wheat.Crop Sci.,50: 73-86.

Shimazaki, Y., Ookawa, T. and Hirasawa, T. 2005. The root tip and accelerating region suppress elongation of the decelerating region without any effects on cell turgor in primary roots of maize under water stress. Plant Physiology, 139(1): 458-465.

Sionit, N., Hellmers, H. and Strain, B. R. 1980.Growth and Yield of Wheat under $\mathrm{CO}_{2}$ Enrichment and Water Stress.Crop Sci.,20: 687-690.

Spollen, W. G., Sharp, R. E., Saab, I. N. and Wu, Y. 1993. Regulation of cell expansion in roots and shoots at low water potentials, in Water Deficits, Plant Responses From Cell to Community, J. A. C. Smith and H. Griffiths, Eds., Bios Scientific Publishers, Oxford, UK, pp. 37-52.

Suhas, K., Shaila C., Rajesh G. and Vasantrao, P.
2012. Developed drought tolerant gene based SSR (DTGB-SSR) markers in wheat. International Referred Research Journal,III(29).

Szegletes, Z. S., Erdei, L., Tari, I. and Cseuz, L. 2000. Accumulation of osmoprotectants in wheat cultivars of different drought tolerance.Cereal Research Communications, 28(4): 403-410.

Tahara, M., Carver, B. F., Johnson, R. C. and Smith, E. L. 1990.Relationship between relative water-content during reproductive development and winter-wheat grainyield.Euphytica,49: 255-262.

Tang, Z. C. 1983. Responses and adaptation of plants to water stress. Plant Physiology Communications, 4: 1-7.

Tuberosa, R. and Salvi, S. 2006. Genomics approaches to improve drought tolerance in crops. Trends Plant Sci, 11:405-412.

Uphaus, J., Walker, E., Shankar, M., Golzar, H., Loughman, R., Francki, M. and Ohm, H. 2007. Quantitative trait loci identified for resistance to Stagonospora Glume Blotch in Wheat in the USA and Australia. Crop Sci.,47: 1813-1822.

Wang, Xu-S., Zhu, J. and Mansueto, L. 2005.Identification of candidate genes for drought stress tolerance in rice by the integration of a genetic (QTL) map with the rice genome physical map.J Zhejiang UnivSci-B,6: 382-388.

Yamasaki, S. and Dillenburg, L. R.1999. Measurements of leaf relative water content in araucaria angustifolia. R. Bras. Fisiol. Veg., 11 (2): 69-75.

Zadehbagheri, M., Azarpanah, A., and Javanmardi, S. 2014. Prolinemetabolite transport an efficient approach in corn yield improvement as response to drought conditions. Nature,566: 76-485.

\section{How to cite this article:}

Raveena, Richa Bharti and Neelam Chaudhary 2019. Drought Resistance in Wheat (Triticum aestivum L.): A Review. Int.J.Curr.Microbiol.App.Sci. 8(09): 1780-1792.

doi: https://doi.org/10.20546/ijcmas.2019.809.206 